\title{
Social entrepreneurship as innovative way of development of small business in the region
}

\author{
Aleksey Panov ${ }^{1 *}$, Natalya Balashova ${ }^{1}$, Olga Zubova ${ }^{1}$, and Aijan Dosova ${ }^{1}$ \\ ${ }^{1}$ Volgograd State Agricultural University, Prospekt Universitetskiy, 26, Volgograd, 400001, Russia
}

\begin{abstract}
This article considers issues of social entrepreneurship as a key tool for solving social problems in society and as a mechanism for changing the very concept of social policy at the state and regional levels. Therefore, the goal of this article is to analyze the current state of social entrepreneurship in the Volgograd region and its relationship with state and non-state actors. The following were used research methods: dialectical method; logical methods of economic research; methods of data analysis and formal logic. Social entrepreneurship in Russia is a new phenomenon compared to Western countries, and the recently emerged sector of the economy has not yet received such development in the subjects of the Russian Federation as abroad. Currently, the social business is not ready to answer a lot of questions related to solving social problems, however, a certain trend in this direction has been set. The state, society, and businesses are slowly moving away from the traditional understanding of the social activities that each of them is accustomed to carry out. The development of social entrepreneurship helps to smooth out pressing issues of society, speeds up their solution by involving a larger number of stakeholders in the issue.
\end{abstract}

\section{Introduction}

In general theory of entrepreneurship, social entrepreneurship is a relatively new subject, and if the discussion on this topic in the Western scientific community has been going on since the 80 s of the XX century, in Russian practice it appeared only 30 years later. The concept of "social entrepreneurship" has recently been enshrined in Russian legislation in July 2019, when amendments to the concepts of "social entrepreneurship" and "social enterprise" were introduced into Federal Law No. 209-FZ "On the Development of Small and Medium-Sized Enterprises in the Russian Federation" (209-Ф3 «On the development of small and medium-sized businesses in the Russian Federation»). According to Article 3 of Federal Law No. 245-FZ, social entrepreneurship is defined as "entrepreneurial activity aimed at achieving socially useful goals, contributing to the solution of social problems of citizens and society ..."

Social business is a very special kind of activity, a kind of brand, which today is spreading both in Russia as a whole and in the Volgograd Oblast in particular. The need for a new format of economic activity and a new way of implementing socially useful ideas

\footnotetext{
*Corresponding author: panov181280@mail.ru
} 
determined the vector of development of social entrepreneurship in the region. This is explained by several reasons, one of which is the interest of the constituent entity of the Russian Federation in the search for entrepreneurs who can fulfill the social obligations of the state and the region while receiving certain support [1].

A social entrepreneur is primarily distinguished by his interest in implementing his socially significant ideas. Making a profit is secondary for them. An equally significant factor for social entrepreneurship is motivation. It can be both external and internal. The support that an entrepreneur receives from a state or region is an external motivation. However, it is less important for an economic entity than internal motivation, which is able to raise the social business to a new level.

\section{Materials and methods}

The study was conducted using data on the functioning of non-profit organizations (NPOs), small and medium-sized enterprises, as well as social enterprises of the Volgograd Oblast, engaged in activities aimed at fulfilling the needs of various socially unprotected groups of the population. The following were used as research methods: the general scientific dialectical method; logical methods of economic research that are playing a crucial role in economic cognition; methods of data analysis and formal logic, a comprehensive assessment methodology for the development of small and medium-sized enterprises in the field of social entrepreneurship

\section{Results}

The creation of favourable economic conditions for the development of entrepreneurship and the systematic improvement of the population's quality of life are the main tasks of the socio-economic policy of the region, which acts as an instrument for implementing the development strategy of the state as a whole and makes it possible to solve priority tasks, including minimizing differences in the Russian Federation subjects' level of social economic development.

A well-thought-out regional socioeconomic policy has long been an independent factor determining economic growth and the growth of well-being of the population, including its most vulnerable parts of it.

The need for regional policy as one of the main levers of state regulation of the socioeconomic sphere is associated with increased territorial imbalances, accompanied by the emergence of depressed regions and zones with mass unemployment [2]. Under these conditions, regional policy should promote the development of industrial and social infrastructure in their territories to maintain structural equilibrium.

Assessment of the socio-economic policy of the region as a necessary part of the mechanism for its implementation is, firstly, a condition for the effective development of measures of a socio-economic orientation, and secondly, the basis for creating a system of recommendations to increase its effectiveness.

Along with the development of the economy, the state of the social sphere of the region determines the general conditions for effective business. This involves searching for and implementation of new ways to attract additional resources to solve socio-economic problems. One of such new ways is social entrepreneurship, which on the one hand is neither a form of corporate social responsibility, nor a new way of providing social services to the population, nor just a social project, but on the other hand, it can develop within any of these forms of activity, such as business and non-profit organizations.

A feature of social entrepreneurship is complex development from the positions of 4 
stakeholders, namely, the state, large business, small business and society (Fig. 1).

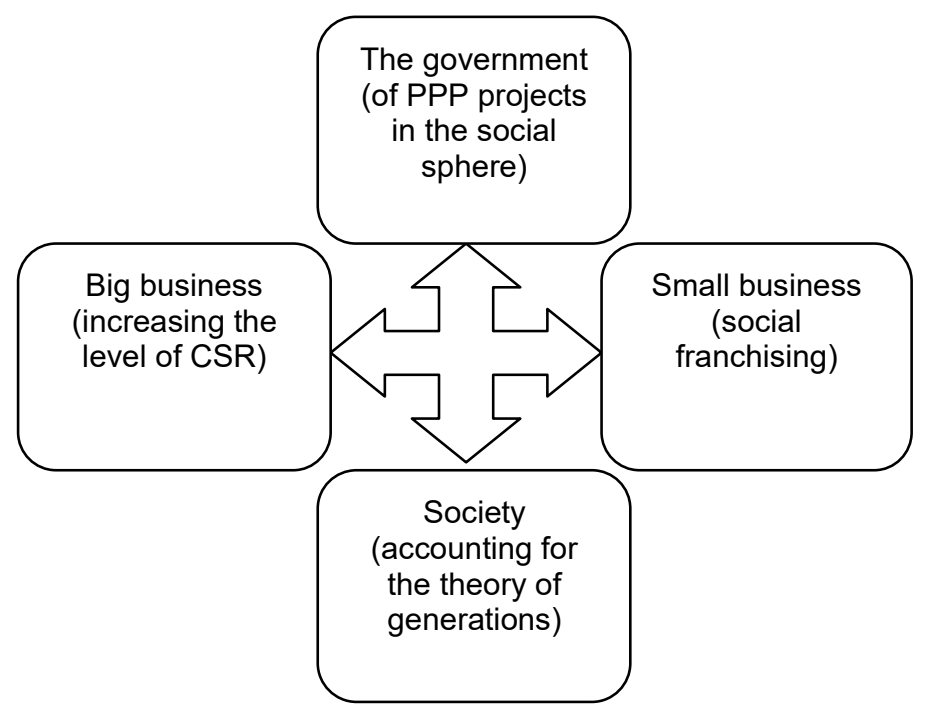

Fig. 1.Main directions of social entrepreneurship development

Today in the Volgograd Oblast the process of popularizing social entrepreneurship is underway: a centre for social sphere innovation, "Volgograd Business Incubator", has been created, the list of social services of organizations has been expanded in the register of suppliers of socially significant products (services), and subsidies and monetary compensations are provided on a competitive basis to entities in this field. However, in the field of social entrepreneurship, there are many problems and issues that need to be addressed, both at the regional level and at the state level. Among them are:

- non-profit organizations lack the necessary knowledge and skills in the business sector;

- lack of regulation;

- low level of development of civic consciousness of the population;

- low coverage of social enterprises' activities;

- high taxes;

- economic instability;

- $\quad$ high level of corruption.

Since 2014, the Administration of the Volgograd Oblast has been working to attract entrepreneurs, as well as NPOs, to provide social services.. For five years, the regional authorities have been interacting with public associations, non-profit organizations and the business community on the implementation of national and priority regional projects, including in the social sphere [3].

The Center for Innovative Social Spheres of the Volgograd Oblast today is a starting base for public entrepreneurs in the region. Since it opened in December 2018) on the basis of the regional business incubator, 985 socially-oriented entrepreneurs of the region have used its services. It helps by mentoring the implementation of entrepreneurial ideas in various fields of activity, including education, healthcare, culture, sports, and in the field of social services for the population. Entrepreneurs have access to support by promoting and popularizing socially-oriented projects, providing information and analytical support as well as open access to educational resources.

Specialists of the Center for Innovative Social Spheres provide information services related to the possibilities of using the advantages established by applicable law; 
operational and financial management, the basics of planning, paperwork, tax, and accounting, legal regulation of activities; conducting marketing research for the implementation of social projects; consultation on the topic of participation in procurement.

In the period from 2015 to 2019 , the Volgograd Oblast is the leader in the number of applications from socially oriented non-profit organizations for the provision of presidential grants. During this time, more than 800 projects received support totalling more than 0.5 billion rubles.

The niche for social entrepreneurship in the regional market today is quite free. To start a social business, a good idea, start-up capital, which can be obtained, including in the form of grant support, as well as internal motivation, is enough.

Social entrepreneurship receives the main support both at the federal and regional levels.

The main foundation that provides assistance in this field both in the Russian Federation as a whole and in the Volgograd Oblast, in particular, is the "Our Future" foundation of regional social programs, whose mission is to promote positive social changes in Russian society by providing support and financing enterprises whose activities are aimed at solving the problems of society.

Center for Social Sphere Innovations of the Volgograd Oblast is providing a serious informational, consulting, legal and educational assistance to small and medium-sized enterprises working in the social sphere or just planning to implement social projects in the future at the regional level. The purpose of its creation and development in the Volgograd Oblast is to create conditions for effective interaction of social entrepreneurs, non-profit and public organizations, investors, state and municipal authorities to ensure the implementation of projects aimed at solving social problems, integrating socially vulnerable categories of citizens into society and the economy, stimulating job creation.

In 2019, the free acceleration program "Social Innovations: Business Start" was launched, organized by the Center for Innovative Social Spheres of the Volgograd Oblast at the "boiling point" site in the Volgograd State Technical University. This event is a series of educational modules aimed at a quick start and business development and is intended not only for entrepreneurs who are already solving acute social problems, but also for other small and medium businesses, ready to develop new directions.

Market participants, which can be attributed to social entrepreneurs, can be divided into three categories. The first ones are representatives of specialized enterprises, such as Cardboard and Bookbinding Factory LLC, the institution of the Volgograd Regional AllRussian Organization All-Russian Society of Disabled People, which produces various containers from corrugated fiberboard and provides people with disabilities with work.

The second category includes non-profit organizations that have taken a commercial benchmark by carrying out entrepreneurial activities that are consistent with the social goals of this organization. In Russia, this type prevails. For example, in Volgograd, the "Healthy Spine" Center has been operating for more than 10 years, providing healthimproving services for people with diseases of the musculoskeletal system.

Third category of social entrepreneurs is small business representatives whose goal is not profit, but the solution of problems of socially unprotected categories of citizens. So, for example, in Volgograd there is a charity foundation called "Childhood Planet", which provides social assistance to various categories of citizens in difficult situations.

The vast majority of organizations that associate themselves with "social entrepreneurship" are not integrated nationwide, and, in most cases, are local, solving the problems of the local community or their own group.

Regulation of the legislative framework in the field of social entrepreneurship, the strengthening of funding and state support at the federal and regional levels will have a beneficial effect on the formation and further development of large social projects. Their 
activities will significantly reduce current social problems.

The introduction of long-term positive transformations in the socio-economic infrastructure of the region is the primary task of the social entrepreneur. At the same time, it is necessary to highlight the fact that the most important part of social entrepreneurship is the ability to move away from the narrow perception of business as commerce and attract disparate resources to improve the lives of people.

\section{Conclusions}

Social entrepreneurship in the Volgograd Oblast is still on the process of it's development; it cannot even be called a full-fledged sector of the economy. In this regard, it is necessary to provide regional assistance in a form of coherent legal regulatory mechanism, which is one of the priority areas of support for the social sphere.

The absence of a special regulatory framework for social entrepreneurship at the regional level entails certain difficulties, which are not easy to distinguish, since they appear in the framework of small and medium-sized enterprises as a whole. In addition, it is this diversity of organizational and legal forms that makes it especially difficult to distinguish between social entrepreneurs and commercial organizations working in the social sphere.

It is obvious that the study of social entrepreneurship in the Volgograd Oblast is a new topic, but at the same time awareness of it is growing rapidly, primarily because of increasing support from state foundations and programs. The growing presence of the concept of "social entrepreneurship" in public discussions, in various media and the Internet, also speaks of its growing popularity, and now only time will be able to show whether social business is able to replace some of the functions of the state (region) responsible for the social sphere.

\section{References}

1. Y. Khaustova, S. Breus, S. Nevmerzhytska, T. Tsalko, T. Kharchenko, Journal of Entrepreneurship Education. 22(1) (2019)

2. A.S. Ovchinnikov, N.V. Ivanova, N.N. Balashova, Espacios, 39(36), 14 (2018)

3. L.V. Popova, D.A. Korobeynikov, O.M. Korobeynikova, A.A. Panov, Journal of Applied Economic Sciences, 11(6), 1034-1044 (2016)

4. L.V Popova, T.A. Dugina, N.S. Panova, A.G. Dosova, N.N. Skiter, Advances in Intelligent Systems and Computing, 622, 681-687, (2018)

5. E.M. Akhmetshin, K.E. Kovalenko, L.V. Goloshchapova, A.G. Polyakova, E.A. Erzinkyan, G.M. Murzagalina Journal of Entrepreneurship Education. 21(S2) 110.(2018)

6. M. Hlady-Rispal, V. Servantie International Journal of Management Reviews. 20(1). 62-80. (2018)

7. E.G. Popkova, M.A. Mitina, T. Litvinova, J. French Espacios. 39(1) 17 (2018) 